\title{
Cementos puzolánicos de mayor resistencia al ataque de aguas selenitosas que los cementos portland de elevada resistencia a las mismas, y viceversa
}

\author{
Puzzolanic cements of greater resistance at the \\ attack of selenitic waters than the high sulfate \\ resistance portland cements, and viceverse $\left(^{*}\right)$
}

\begin{abstract}
RESUMEN
Este trabajo confirman las prediciones de vida útil dadas por Kalousek y colaboradores, para los cementos portland de elevada resistencia al ataque de los iones sulfato (tipo V, USA), sometidos a un severo ataque selenitoso.

Se ensayaron dos cementos portland de elevada resistencia al ataque del yeso, mediante el ensayo de Le Chatelier-Anstett. Sus tortas correspondientes se destruyeron a la edad de tres años, habiéndose detectado en las mismas la presencia de thaumasita por DRX.
\end{abstract}

Asimismo se confirmó la imposibilidad y posibilidad de formación de thaumasita en tortas de cementos puzolánicos, los cuales tenian, o no, respectivamente, una adecuada cantidad de puzolana (diatomita) para tales fines.

\begin{abstract}
SUMMARY
This work confirms the certainty of the predictions of useful service given by Kaluosek and al. for the sulphate resistant portland cements (type V, USA), subject to severe selenitic attack.

Two sulphate resistant portland cements, were tested by means of the Le Chatelier Anstett method. The tarts were destroyed at ages of three years, having detected in them the presence of thaumasite by XRD.
\end{abstract}

Even so, the impossibility and possibility thaumasite formation was confirmed in pozzolanic cements tarts, which either had or did not have adequate amount of pozzolana (diatomite) for such purpose.

\section{INTRODUCCION}

La durabilidad de las estructuras de hormigón es de capital importancia, y el ataque sulfático es una de las formas más conocidas de deterioración del mismo. Como se sabe, verificase preferentemente dicho ataque sulfático a través del $\mathrm{C}_{3} \mathrm{~A}$ del cemento portland, para formar ettringita expansiva.

$$
\begin{aligned}
& \mathrm{C}_{3} \mathrm{~A}+3 \mathrm{CaSO}_{4} \cdot 2 \mathrm{H}_{2} \mathrm{O}+25 \mathrm{H}_{2} \mathrm{O} \rightarrow \\
& \rightarrow \mathrm{C}_{3} \text { A.CaSO } 4.31 \mathrm{H}_{2} \mathrm{O}
\end{aligned}
$$

Tal ataque se trató de dificultar mediante la creación de los cementos portland de elevada resistencia al ataque de los iones sulfato, como son los cementos de contenido de $\mathrm{C}_{3} \mathrm{~A}$ bajo o escaso, y generalmente menor del

\section{INTRODUCTION}

Durability of concrete structures is of the utmost importance and sulphate attack is one most well forms of concrete deterioration. As it is known, it is verified preferably through the $\mathrm{C}_{3} \mathrm{~A}$ portland cement concrete to forms expansive ettringite,

$$
\begin{gathered}
\mathrm{C}_{3} \mathrm{~A}+3 \mathrm{CaSO}_{4} \cdot 2 \mathrm{H}_{2} \mathrm{O}+25 \mathrm{H}_{2} \mathrm{O} \rightarrow \\
\rightarrow \mathrm{C}_{3} \mathrm{~A} .3 \mathrm{CaSO}_{4} \cdot 31 \mathrm{H}_{2} \mathrm{O}
\end{gathered}
$$

Such nocive effect was treated to elude that by means of creation sulphate resistant portland cements, as are the cements $\mathrm{C}_{3} \mathrm{~A}$ small content and generally less $5 \%$. For that reason, althoug the bibliography that is written at

(*) Presentado al "8." Congreso Internacional de Química do Cemento", Rio de Janeiro, Brasil, 22-27 Septiembre 1986. 
$5,0 \%$. Por lo tanto, si bien la bibliografía existente sobre el ataque sulfático al $\mathrm{C}_{3} \mathrm{~A}$ es muy abundante, no lo es tanto aquella que trata de la posible deterioración de pastas, morteros $u$ hormigones de tales tipos de cementos de elevada resistencia sulfática, pues sólo se sabe generalmente que:

1. El $\mathrm{C}_{4} \mathrm{AF}$ también puede ser atacado por los sulfatos aunque más lentamente que el $\mathrm{C}_{3} \mathrm{~A}$.

$$
\begin{aligned}
& \mathrm{C}_{4} \mathrm{AF}+3 \mathrm{CaSO}_{4} \cdot 2 \mathrm{H}_{2} \mathrm{O}+29 \mathrm{H}_{2} \mathrm{O} \rightarrow \\
\rightarrow & \mathrm{C}_{3} \mathrm{~A} .3 \mathrm{CaSO}_{4} .31 \mathrm{H}_{2} \mathrm{O}+\mathrm{CH}+\mathrm{FH}_{3}
\end{aligned}
$$

2. H. Kühl clasifica a las sales complejas del ion $\mathrm{Fe}^{3+}$ también en dos tipos, como las del ion $\mathrm{Al}^{3+}: \mathrm{C}_{3} \mathrm{~F} .3 \mathrm{CaSO}_{4} .31 \mathrm{H}_{2} \mathrm{O}$ y $\mathrm{C}_{3} \mathrm{~F}_{\mathrm{CaSO}} .12 \mathrm{H}_{2} \mathrm{O}(3)$, respectivamente, ambos simbolizados por SFCH.

Esto, unido a:

- el grave problema de terrenos selenitosos que muchos países mediterráneos poseen, y

- a las correspondientes investigaciones llevadas a cabo por Kalousek y cols. (4), en las que confirma que las esperanzas de vida de determinados hormigones de cemento tipo V USA son menores de 50 años, merced al ataque severo de los mismo por $2,1 \% \mathrm{Na}_{2} \mathrm{SO}_{4}$ sin aportar la causa intrínseca verdadera de su deterioro, ha justificado la realización de este trabajo al objeto de:

- reproducir, en su fundamento, los hechos preconizados por Kalousek y cols. (4),

- demostrar que los mismos se pudieron originar a través de la pasta cementante de tales hormigones y, más concretamente, a través del $\mathrm{C}_{4} \mathrm{AF}$,

- averiguar las causas reales de la nocividad de dicho ataque, o compuestos cristalinos resultantes del mismo, y

- tratar de remediarlas.

\section{PARTE EXPERIMENTAL}

Teniendo en cuenta que el método de ensayo de Le Chatellier-Anstett, L-A (5) es, prácticamente, el más severo de todos los que present about sulphate attack at the $C_{3} A$, is very abundant, it is noy the same for the sulphate attack $C_{4} A F$ and deterioration possible of the concretes of sulphate resistant portland cement, because it only is a generally form:

1. The $C_{4} A F$ also can be attacked for sulphates, however more slowly that the $C_{3} A(2)$

$$
\begin{aligned}
& \mathrm{C}_{4} \mathrm{AF}+3 \mathrm{CaSO}_{4} .2 \mathrm{H}_{2} \mathrm{O}+29 \mathrm{H}_{2} \mathrm{O} \rightarrow \\
& \rightarrow \mathrm{C}_{3} \mathrm{~A} .3 \mathrm{CaSO}_{4} .31 \mathrm{H}_{2} \mathrm{O}+\mathrm{CH}+\mathrm{FH}_{3}
\end{aligned}
$$

2. H. Kühl clasified the complex salts of $\mathrm{Fe}^{3+}$ ion two types, in the same forms of $\mathrm{Al}^{3+}$ ion:

$$
\begin{aligned}
& \mathrm{C}_{3} \mathrm{~F} .3 \mathrm{CaSO}_{4} .31 \mathrm{H}_{2} \mathrm{O} \text { and } \\
& \mathrm{C}_{3} \mathrm{~F}_{\mathrm{CaSO}} .12 \mathrm{H}_{2} \mathrm{O}(\overline{\mathrm{SFCH}})
\end{aligned}
$$

All that connected,

- with serious problem of gypsipherous terrains that have much mediterranean regions, and

- the publication of Kalousek at al. (4), where they confirms that concretes made with Type $V$ and II portland cements showed life expectancies of less than 50 years and that limitations on $C_{3} A$ and $C_{4} A F$ contents are not the ultimate anser to the problem of sulphate attack; and that by means of severe attack with $\mathrm{Na}_{2} \mathrm{SO}_{4}, 2,1 \%$, didn't give the intrinsic cause of their damage, that has justified the realization of this woek, with this purpose:

- to reproduce, in their foundation, the acts preconized by Kalousek et al.

- to demostrate thet the same facts could be origined by means of cement paste of these concretes, and more concretely, by means of $\mathrm{C}_{4} \mathrm{AF}$,

- to investigate the certains causas of the nocivity of that attack, or crystalline compounds resulting of this attack, and

- ti treat to remedy that.

\section{EXPERIMENTAL PROCEDURE}

Taking into consideration the fact Le ChatelierAnstett, $L-A$, test (5), is practically the more severe of all there are to mesure the grade of 
existen para medir el grado de resistencia sulfática de un cemento, se utilizó el mismo:

- por su condición de acelerado,

- porque en determinadas ocasiones pueden llegar a reproducirse en la realidad sus condiciones muy severas de hidratación selenitosa; por ejemplo, en túneles de trasvases de agua o conducciones subterráneas o aéreas de agua, ambos en terrenos yesíferos, $y$

- para tratar de confirmar de hecho que, en su caso, la deterioración de hormigones confeccionados con cementos portland de elevada resistencia sulfática puede provenir del ataque selenitoso a su pasta cementante.

Por lo tanto, se ensayaron mediante el método L-A, dos cementos tipo V, PY-4 y PY- 6 , y cuatro de mezcla con puzolana D(diatomita), PY-4/D $80 / 20$ (80 \%, en peso, PY-4 $+20 \%$, en peso, puzolana D), PY-4/D 70/30 (70\%, en peso, $\mathrm{PY}-4+30 \%$, en peso, puzolana D), PY-6/D 80/20 y PY-6/D 70/30 (véase la Tabla 1).

No obstante, antes de proceder al ensayo de los mismos mediante el método de L-A se trató de ver si el cemento PY-6, 79,43\% $C_{3} S$, y la puzolna $D$, tanto juntos como separados, eran capaces de originar ettringita y/o thaumasita y/o SSCH y/o SFCH, en un medio portlandítico y selenitoso apropiados, así como también la posibilidad de su permanencia respectiva en dicho medio hasta la edad de 730 días y en su estudio semi-cuantitativo correspondiente por DRX. Para ello se les ensayó conforme indica expresamente el ensayo de Fratini (6) aunque con un exceso notable de yeso o "Fratini Selenitoso", habiendo sido la dosificación de materiales de cada uno de ellos la reflejada en la Tabla 2. sulphatic resistance of cement, it was employed that same,

\section{- by it condition of acelerated,}

- because in determined occasions can be reproduced in the reality the very rigorous conditions of selenitic hydration, for instance in the tunnels to overflow of water or subterranous or aerial conductions of water, both in gypsipherous terrains, and

- to try to verify the fact which the deterioration of sulphate resistant portland cement concretes can proceed of the selenitic attack at the cement paste.

Therefore were tested by means of L-A method, two portland cements Type V, PY-4 and PY-6, and four mixture cements with pozzolana $D$ (diatomite), PY-4/D 80/20 (80\% in wt. PY-4, $20 \%$ in wt. Pozzolana D), PY-4/D $70 / 30(70 \%$ in wt. PY-4, $30 \%$ in wt.

Pozzolana D) PY-6/D 80/20 and PY-6/D 70/30, Table 1.

Nevertheless, before make the test of them by means of L-A method, was tried to see if the PY-6 $\left(79,43 \% C_{3} S\right)$ cement and the pozzolana $D$, mixeda and not mixeds, was wides to origine ettringite and/or thaumasite and/or $\overline{S S C H}$ and/or SFCH, in a apropiate portlanditic and selenitic medium, in the same maner the possibility of it respective permanency in such medium until age 730 days old and their respective semi-quantitative study of the $X$-ray diffraction analyses. For that they were tested by means of Fratini test, although with a notable excess of gypsum or "Gypsipferous Fratini". The dosification of respective materials were the following, Table 2.

TABLE 1

Chemical and Potential Mineral Composition

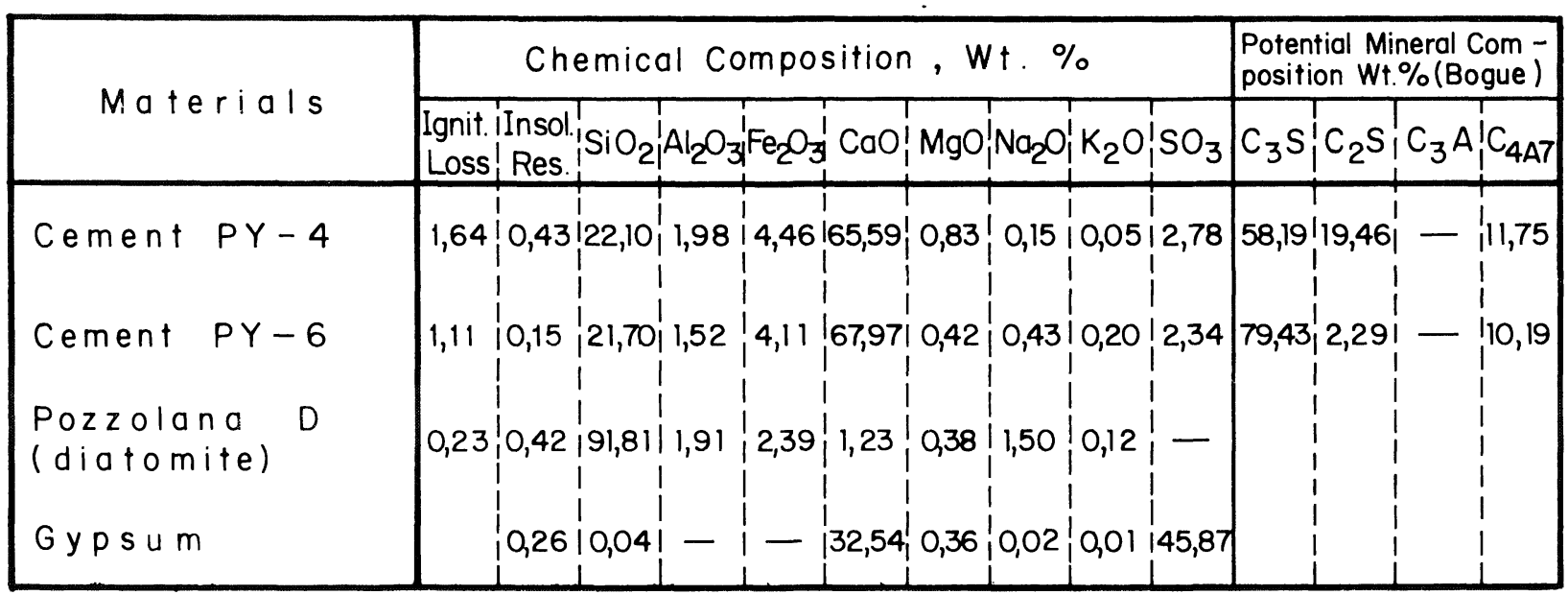


A las edades de $1,7,14,21,28,60,90,270$ y 730 días, se tomó muestra de la fase sólida de cada una de las mezclas-conglomerantes de la Tabla 2 y se procedió para su examen por DRX.

Como es sabido, si el contenido de $\mathrm{SO}_{4}$ Ca. $2 \mathrm{H}_{2} \mathrm{O}$ de una torta del método de L-A es del $33,33 \%$ ó $15,50 \%$ de $\mathrm{SO}_{3}$ en los ensayos previos anteriores se trató de horquillar dicho contenido mediante los contenidos del $7,0 \%$ y $21,0 \%$ de $\mathrm{SO}_{3}$, respectivamente, ya que lo que ocurra en cada torta habrá de estar comprendido necesariamente entre lo formado en las mezclas-conglomerantes del $7,0 \%$ y $21,0 \%$ de $\mathrm{SO}_{3}$ correspondientes de este ensayo previo.

Igualmente de las tortas L-A deterioradas se realizó un examen por DRX con idéntico fin anterior.

Para realizar los análisis por DRX se ha utilizado un equipo automático con un Software analítico con mini-ordenador Digital PDP 11/24.

\section{RESULTADOS Y DISCUSION}

Los resultados experimentales obtenidos se encuentran en las Tablas 3 y 4, Fig. 1, en las Fotos 1 y 2 y en los gráficos DRX 1, 2 y 3 .

TABLE 2

Materials Dosification

"Gypsiferous Fratini" Test

\begin{tabular}{|c|c|c|c|c|}
\hline & \multicolumn{2}{|c|}{ PY-6 } & $\begin{array}{l}P Y-6 / D \\
70 / 30\end{array}$ & PUZ D \\
\hline & \multicolumn{3}{|c|}{$\mathrm{SO}_{3}$ Conglomerant } & -Mixture \\
\hline & $7,0 \%$ & $21,0 \%$ & $7,0 \%, 21,0 \%$ & $7,0 \% 21,0 \%$ \\
\hline Cement (g) & $|7,86|$ & 11,43 & $14,08: 9,01$ & $-1-$ \\
\hline Pozzolana D(g) & -1 & - & $3,52,2,25$ & $4,78,3,09$ \\
\hline $\begin{array}{l}\text { Gypsum (g) } \\
\mathrm{Ca} \mathrm{SO}_{4} \cdot 2 \mathrm{H}_{2} \mathrm{O}\end{array}$ & 2,14 & 8,57 & \begin{tabular}{|l|l|}
2,40 & 8,74 \\
\end{tabular} & \begin{tabular}{l|l}
3,01 & 19,03 \\
\end{tabular} \\
\hline $\begin{array}{l}\mathrm{Ca}(\mathrm{OH})_{2} \\
\text { R.A. (g) }\end{array}$ & 一 & 一 & $-1-$ & \begin{tabular}{l|l}
12,21 & 7,88 \\
\end{tabular} \\
\hline TOTAL $(g)$ & 20,00 & 20,00 & $20,00,20,00$ & $20,00 \mid 20,00$ \\
\hline $\mathrm{H}_{2} \mathrm{O}$ d. (cc) & 100 & 100 & $100: 100$ & 100 \\
\hline
\end{tabular}

At the ages of $1,7,14,21,28,60,90,270$ and 730 days, were saized sample of solid phase of each of tha conglomerant-mixtures of the Table 2, and it was proceded at their examination by $X R D$.

As it is known, the content $\mathrm{CaSO}_{4} \cdot 2 \mathrm{H}_{2} \mathrm{O}$ of a tart of $L-A$ method is 33,33\% in wt., or $15,50 \%$ $\mathrm{SO}_{3}$, for this reason in the ultimate previous tests was pitchforked that content by means of the contens of $7,0 \%$ and $21,0 \% \mathrm{SO}_{3}$, respectively, because all that occurres at each tart it will have be necessarily formed in the conglomerant-mixtures inter $7,0 \%$ and $21,0 \%$ $\mathrm{SO}_{3}$ correspondents, in this previous test.

Equally for the damaged L-A tarts was realized a examination by XRD with the same objetive.

To realize the analysis by $X R D$ it has been employed a automatic equip with an analytic Software with smoll-orderer DIGITAL PDP $11 / 24$

\section{RESULTS AND DISCUSSION}

The experimental results obtained are in the Tables 3 and 4, Figs. 1 a) and b), Phots. 1 and 2 and in the Graphics 1,2 and 3.

TABLE 3

Fratini Test

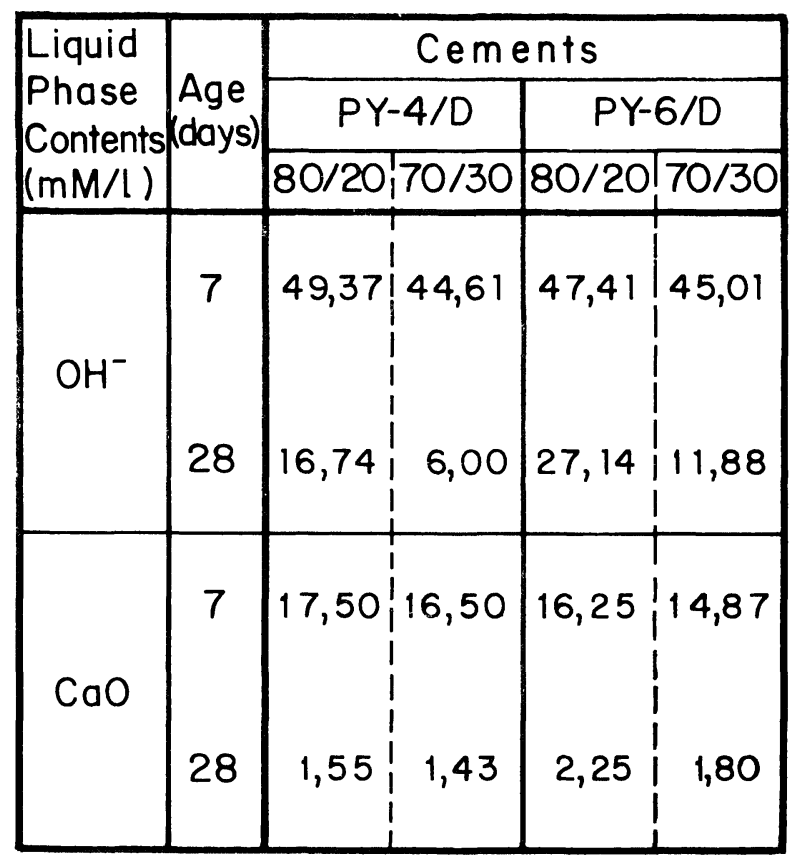


TABLE 4

Le Chatelier-Anstett Test

\begin{tabular}{|c|c|c|c|c|c|c|}
\hline \multirow{2}{*}{$\begin{array}{c}\text { Age } \\
\text { (days ) }\end{array}$} & \multicolumn{5}{|c|}{ Expansión, $\Delta \varnothing(\%)$} \\
\cline { 2 - 6 } & $P Y-4$ & $P Y-6$ & \multicolumn{2}{|c|}{$P Y-4 / D$} & \multicolumn{2}{c|}{$P Y-6 / D$} \\
\hline 28 & 0,13 & 0,75 & 0,25 & 0,25 & 0,37 & 0,25 \\
\hline 90 & 0,25 & 1,20 & 0,25 & 0,25 & 0,44 & 0,25 \\
\hline 365 & 1,00 & 3,49 & 0,50 & 0,25 & 0,62 & 0,37 \\
\hline 1095 & 10,43 & 22,88 & 0,80 & 0,55 & 11,22 & 0,63 \\
\hline 1460 & 38,67 & 52,25 & 0,85 & 0,60 & 17,23 & 0,70 \\
\hline
\end{tabular}

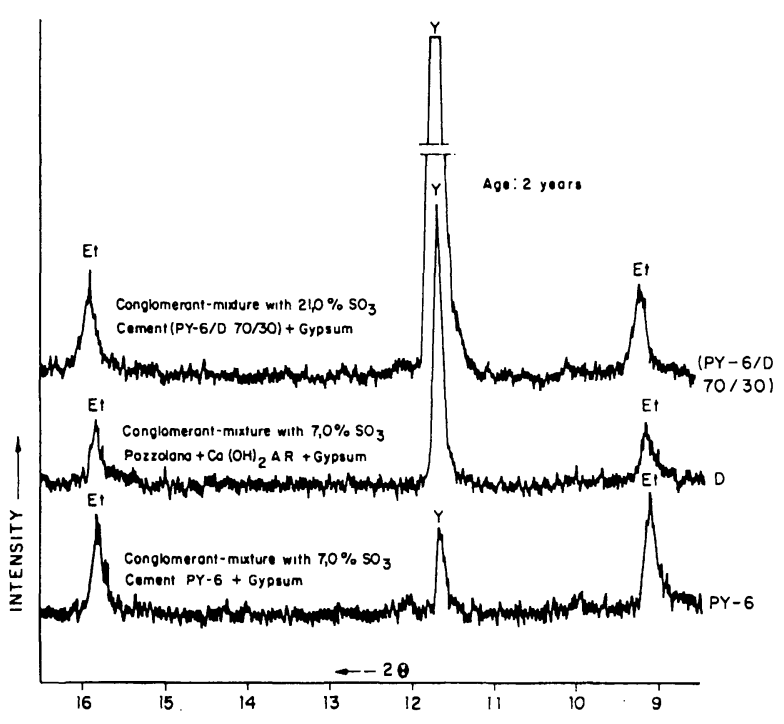

Gráfico 1

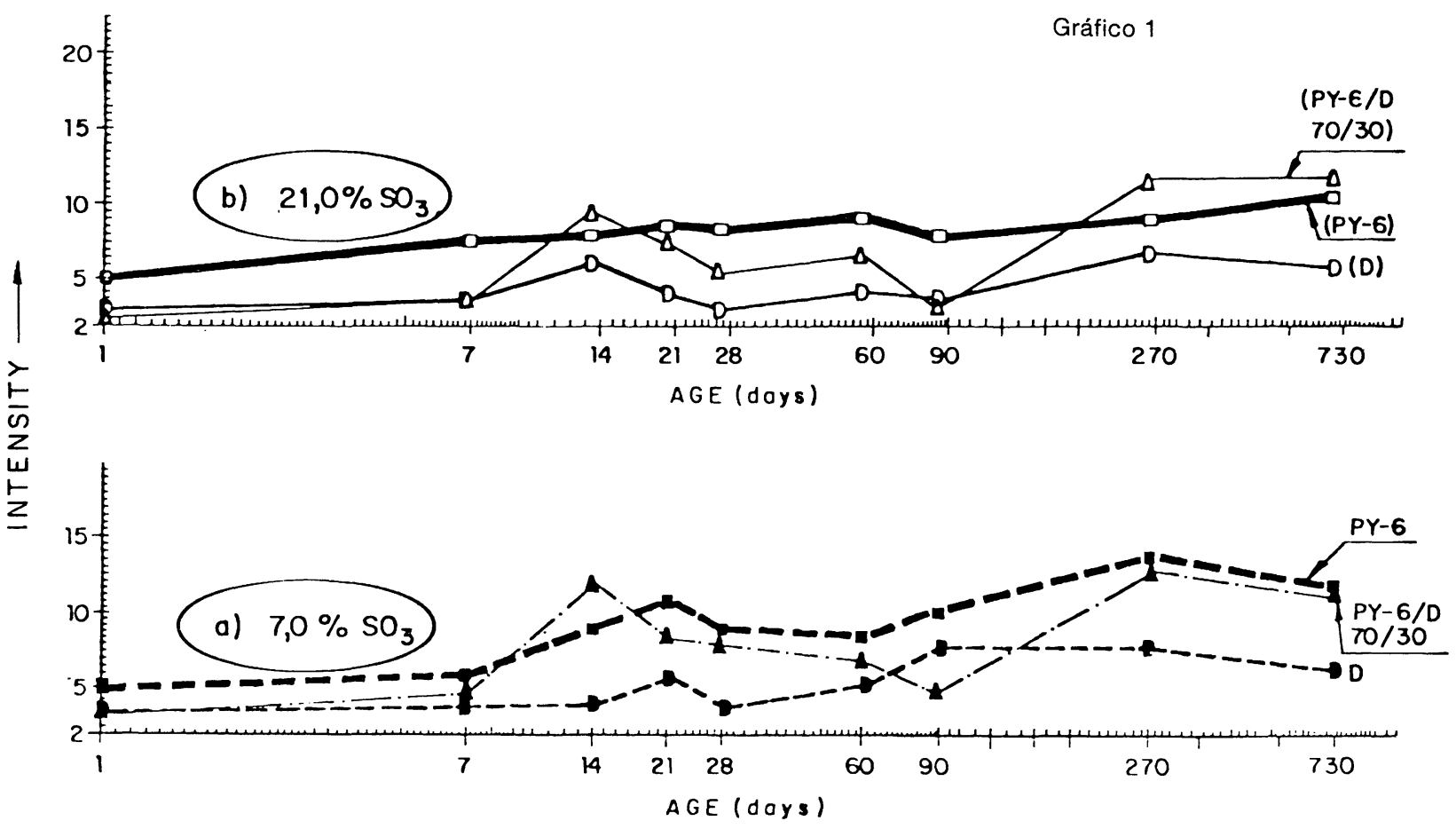

Fig. 1.-Semi-cuantitative analysis of diferents cements. "Gypsipherous Fratini" test.

\section{III.1. Fratini Selenitoso}

La Fig. 1 a) y b) confirma que en el ensayo de Fratini con yeso o "Fratini selenitoso", prácticamente exento de $\mathrm{CO}_{2}$ durante los 730 días de su duración, se forma solamente ettringita en todos los casos, la cual se mantiene a lo largo de todo el ensayo, tanto con $7,0 \%$ como con $21,0 \%$ de $\mathrm{SO}_{3}$, puesto que ha existido contenido de yeso y $\mathrm{Ca}(\mathrm{OH})_{2}$ sintético o R.A., necesarios y suficientes, para su mantenimiento. Por otra parte está demostrado que aquellos cementos portland que, mediante el cálculo de Bogue no poseen $\mathrm{C}_{3} \mathrm{~A}$, prácticamente suelen tener del $0 \%$ al $2 \%$ de $C_{3} A$, en cuyo caso más desfavorable,

\section{III.1. "Gypsipherous Fratini”}

The Figs. 1 a) and b), confirm thet in the "Gypsipherous Fratini", practically without $\mathrm{CO}_{2}$ during 730 days, ettringite is formed only, in all cases, it is supported during all test, in the $7,0 \% \mathrm{SO}_{3}$ case and in the $21,0 \mathrm{SO}_{3}$ case, since it has had quantity of gypsum and $\mathrm{Ca}(\mathrm{OH})_{2}$ synt., or A.R., neccesary and sufficient for it maintenance. It is demostrated that with those portland cements that by means of Bogue calculation have not $C_{3} A$, practically have of $0 \%$ at $2 \% C_{3} A$, in the case most unfavourable $2 \% \mathrm{C}_{3} \mathrm{~A}$, would necessitata by calculations $1,84 \% \mathrm{SO}_{3}$ to pass at ettringite, for this in both cases of $7,0 \%$ and $21,0 \% \mathrm{SO}_{3}$, have sufficient 
$2 \% \mathrm{C}_{3} \mathrm{~A}$, necesitaría un $1,78 \%$ de $\mathrm{SO}_{3}$ para pasar a ettringita, por lo que en ambos casos del $7,0 \%$ y $21,0 \%$ de $\mathrm{SO}_{3}$, hay yeso suficiente para la formación y permanencia de la misma durante todo el ensayo y aún a edades posteriores, puesto que el hermetismo del ensayo de Fratini al impedir la carbonatación gypsum fot the formation and permanency the same of the origined strong during all test and yet at advance ages, since the hermetic of the recipient of gypsipherous Fratini (avoiding the permanent carbonation of the synthetical or A.R. $\mathrm{Ca}(\mathrm{OH})_{2}$ ], permitted it. For this cause must not estrange the formation of ettringite of
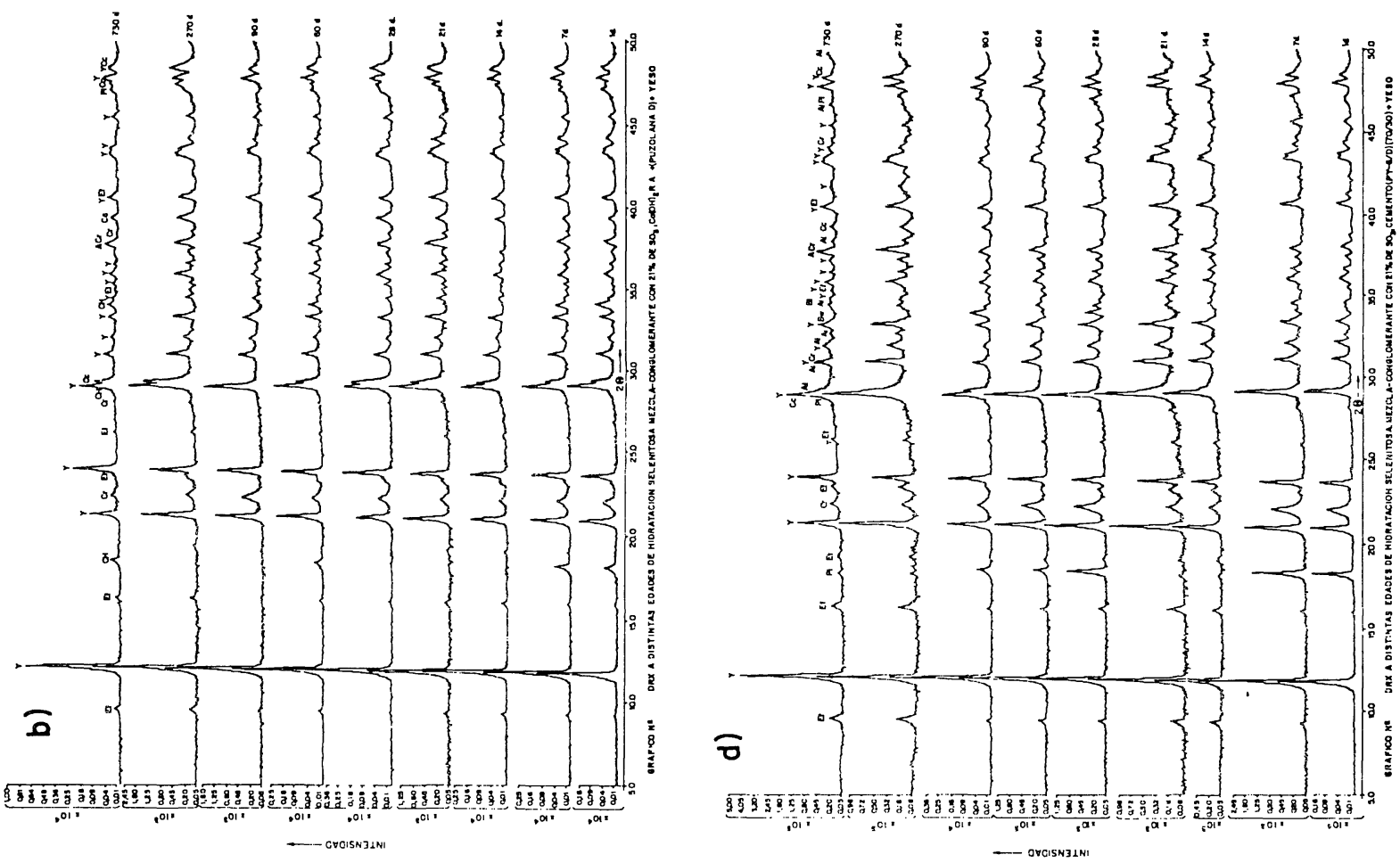

$N$
0
$\frac{0}{0}$
$\frac{0}{0}$
0
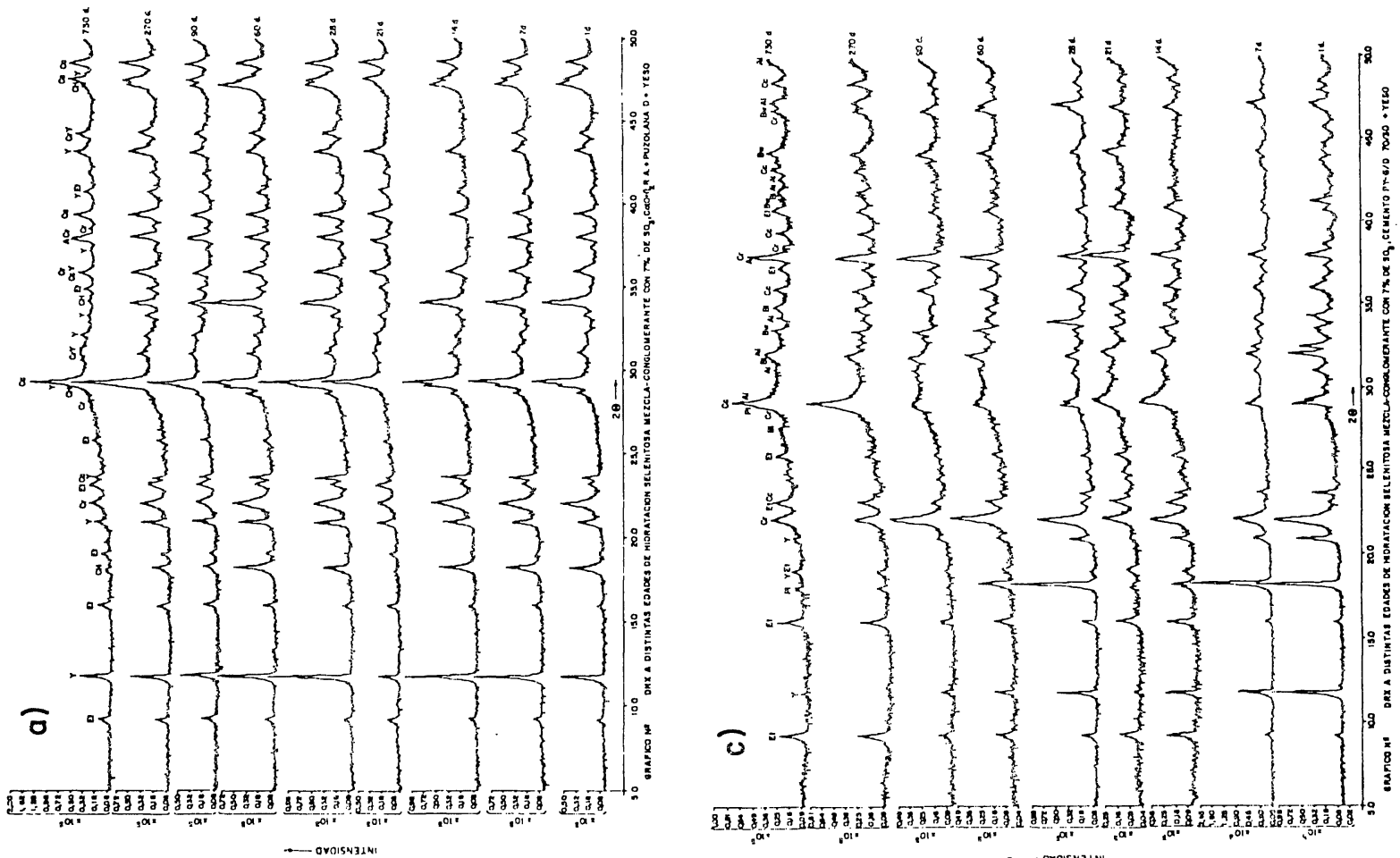
del $\mathrm{Ca}(\mathrm{OH})_{2}$ sintético o R.A., se lo permite. Por ello no debe extrañar la formación de ettringita de distinto origen y etiología, la cual ha de provenir:

\section{- en el caso del cemento PY-6:}

- o bien de su muy escaso contenido posible $\mathrm{C}_{3} \mathrm{~A} \simeq 1,0 \%$, hecho improbable,

- o bien del $\mathrm{C}_{4} \mathrm{AF}$-véase gráfico 2, y en particular el segundo máximo de la Fig. 1 a) y b)-,

- o bien de ambos anteriores a una misma o distinta edad;

- en el caso de la puzolana D, de su escaso contenido de $\mathrm{Al}_{2} \mathrm{O}_{3}$, más bien en forma de "Alúmina reactiva", y

- en el caso de cemento PY-6/D 70/30, de las fracciones respectivas de ambos PY-6 y D.

Por otra parte, de la forma sinusoidal y ascendente de la curva del PY-6 con 7,0\% de $\mathrm{SO}_{3}$ se desprende el hecho de que, pese a haberse formado la mayor parte de la ettringita a la edad de 21 días, la misma no ha debido alcanzar aún su totalidad, lo cual se va consiguiendo al parecer algo más lentamente, conforme transcurre el ensayo, sin poderse precisar para entonces si de origen $\mathrm{C}_{3} \mathrm{~A}$ residual, si de $C_{4} A F$ o si de ambos a un mismo tiempo, pudiéndose decir con mayor razón aún otro tanto, en el caso del $21,0 \%$ de los $\mathrm{SO}_{3}$, donde la ascensión es clara y manifiesta. Por todo lo cual se puede decir con fundamento y de una forma aproximada, que la cantidad de ettringita se ha duplicado desde el principio 1 día al fin del ensayo, 730 días, y potencialmente más aún en el caso del $21,0 \%$ de $\mathrm{SO}_{3}$ que en el caso del $7,0 \%$ de $\mathrm{SO}_{3}$, pues en el supuesto teórico probable de que el contenido de $\mathrm{C}_{3} \mathrm{~A}$ del cemento PY- 6 fuera el $1,0 \%$, por estequiometría la cantidad de ettringita que se formaría por $1 \mathrm{~g}$ de $\mathrm{C}_{3} \mathrm{~A}$ sería $4,55 \mathrm{~g}$, en el caso del $7,0 \%$ de $\mathrm{SO}_{3}$ y $4,45 \mathrm{~g}$ en el caso de $21,0 \%$ de $\mathrm{SO}_{3}$; de aquí la escasa diferencia de intensidad de pico de las ettringitas respectivas a la edad de 730 días en ambos casos del $7,0 \%$ y $21 \%$ de $\mathrm{SO}_{3}$ -Fig. 1 a) y b)-.

Por el contrario, y en el caso de la puzolana D, el retraso de 7 días mostrado en la aparición del primer máximo de ettringita, en el caso del $7,0 \%$ de $\mathrm{SO}_{3}$, respecto al correspondiente al $21,0 \%$ de $\mathrm{SO}_{3}$, se puede deber al hecho de que tanto la mayor presencia de la misma, como las mejores condiciones de $\mathrm{pH}$ del medio (el pH de una disolución saturada de sulfato cálcico $0,12 \% \mathrm{SO}_{3}$ es 6,3 , y puede different origins and etiologies, that must comme:

- In the case of cement PY-6,

- or well of it small possible of $C_{3} A 1,0 \%$, cause improbable enough,

- orwell of $A l$ ion of the $C_{4} A F$, Graphics 1 and 2 ,

- or well of both a same or different age,

- in the case of the pozzolana $D$, of it small content of $\mathrm{Al}_{2} \mathrm{O}_{3}$, more in form of reactive alumine, and

- in the case of cement PY-6/D 70/30, of the respective fractions of $P Y-6$ and $D$.

On the other hand tha synousidal and ascendent form curve of PY-6 with $7,0 \% \mathrm{SO}_{3}$, is deduced that in spite of having been formed the greatest part of ettringite at the age of 21 days which still has not must be obrained the totality it seems that this is lograted something more slowly according to progress the test it can not be precised if is of residual $C_{3} A$ origin (improbable fact) or origin $C_{4} A F$ (more probable fact). The same can be said, still with more reason in the case of 21,0) $\mathrm{SO}_{3}$ where the ascension is clear. For this reason it can be said with foundation and the a forme approximate, that the amount of ettringite have been duplied from start, 1 day, to end, 730 days, more yet and potentially in the case $21,0 \% \mathrm{SO}_{3}$ that in the case $7,0 \% \mathrm{SO}_{3}$, then in the theoric supposition that the $C_{3} A$ content of PY-6 cement was $1,0 \%$, by calculations the cuality of ettringite that would be formed by $1 \mathrm{~g} \mathrm{C}_{3} \mathrm{~A}$ would be $4,55 \mathrm{~g}$, in the case $7,0 \%$ $\mathrm{SO}_{3}$, and 4,54 $\mathrm{g}$ in the case $21,0 \% \mathrm{SO}_{3}$, for this reason the small difference of intesity pick of the respective ettringite at the time of 730 days, in both cases, $7,0 \%$ and $21,0 \% \mathrm{SO}_{3}$, Figs. 1 a) and b).

Un the contrary and in case of the pozzolana $D$ the delay of 7 days showed in the appearance of the firts maximun of ettringite in the case $7,0 \% \mathrm{SO}_{3}$, in relation with the of $21,0 \% \mathrm{SO}_{3}$, it can be for the fact that so the greatest presence of pozzolana $D$ as the best conditions of $\mathrm{pH}$ of medium (the $\mathrm{pH}$ of one satured $\mathrm{CaSO}_{4}$ solution, $0,12 \% \mathrm{SO}_{3}$, is 6,3 , and must be performed by more time with 
mantenerse durante más tiempo con $21,0 \%$ de $\mathrm{SO}_{3}$ que con $7,0 \%$ de $\mathrm{SO}_{3}$ ) deben facilitar el que los geles tobermoríticos de neoformación y origen puzolana $D$ (no detectables por DRX, Gráfico 2) (8), pueden formarse, quizás, antes en el primer caso, $7,0 \%$, que en el segundo, $21.0 \%$, dificultando así antes el trasiego iónico, y retrasando de este modo la formación del total respectivo de ettringita que de dicha puzolana se deriva. Además, el haberse repetido este hecho en el caso del cemento PY-6/D 70/30 con 7,0 \% y $21,0 \%$ de $\mathrm{SO}_{3}$, respectivamente, amplía quizás la posibilidad apuntada del probable comportamiento específico de cada tipo de gel tobermorítico de la puzolana $D$ en cada caso; pues aunque en tales casos citados, cemento PY-6/D $70 / 30$ con $7,0 \%$ y $21,0 \%$ de $\mathrm{SO}_{3}$, dichos geles tobermoríticos respectivos fueran exactamente iguales a cuando la puzolana $D$ estuvo sola, lo que ya no sería igual es la cantidad total de ettringita formada correspondiente, la cual sería lógicamente mayor, respectivamente en ambos, a cuando la puzolana $D$ estuvo sola, ya que la ettringita de origen, fracción cemento matriz PY- 6 , aunque escasa como la de la puzolana $D$, también cuenta. $Y$ ante estas nuevas cantidades pequeñas de ettringita total formada en cada caso, pero mayores respectivamente a cuando la puzolana $D$ estuvo sola, puede que dichos geles tobermoríticos, antes citados, seán aún los adecuados para dificultar el trasiego iónico necesario para impedir-retrasar la formación de aquélla, en cada caso, hasta la edad de 21 días, y no en cambio a cuando la puzolana $D$ estuvo sola con $21,0 \%$ de $\mathrm{SO}_{3}$, como ha ocurrido en este trabajo.

Todo ello apunta, por tanto, la idea de que, al parecer, cada cantidad total de ettringita a formar, en cada caso, necesita un determinado tipo de gel tobermorítico en calidad y cantidad precisas y adecuadas para impedir o retrasar notablemente su formación.

Por otra parte, el hecho de que en todos los casos se mantenga e incluso aumente la escasa cantidad de ettringita inicialmente formada, a pesar de la presencia de la puzolana $D$ en todos ellos, apunta la idea de que la velocidad de formación de los geles tobermoríticos ha de ser en las edades iniciales del ensayo apreciablemente menor que la velocidad de formación de la ettringita de culquier origen, pues en caso contrario ésta no debería aparecer desde el principio.

También y como se habrá podido observar, anteriormente se ha hablado de geles tobermoríticos (y no de tobermorita cristalina I y II de Taylor, pues la Gráfica 2 de DRX no confirma la presencia de las mismas) los cuales han de existir en el medio a tenor de
$21,0 \% \mathrm{SO}_{3}$ that with $7,0 \% \mathrm{SO}_{3}$ ) must facilite that tha new-formation and origin pozzolana $D$ tobermoritic gels (not detected by XRD or X-ray diffraction analyses, Graphic 2) (8), can be formed, perhaps, before in the firts casa, 7,0\% $\mathrm{SO}_{3}$, that in the second case, $21,0 \% \mathrm{SO}_{3}$, difficulting so before the ionic overset, and setting back of this manner the formation of the respective ettrigite total wich of this pozolana $D$ is origined. Furthermore, to have been repeated this in the case of the cement PY-6/D 70/30 with $7,0 \%$ and $21,0 \% \mathrm{SO}_{3}$, respectivelly amplifies, perhas, the possibility indicated of the specific actuation probable of each type of tobermoritic gel of the pozzolana $d$, in each case; therefore although in such related cases, cement PY-6/D 70/30 with 7,0\% $\mathrm{SO}_{3}$ and $21,0 \% \mathrm{SO}_{3}$, such tobermoritic gels respectives were accurantly equals when the pozzolana $D$ was only, which was not equal is the total cuantity of formed ettringita correspondent, that would be logically greatest, respectively in both when the pozzolana $D$ was only, therefore the ettringite of origin fraction matrix cement PY-6, althoug small as of the pozzolana $D$, also has be considered, and in from of news small cuantities of total ettringite formed in each case, but gretest respectively, that when the pozzolana $D$ was only, perhaps the referied tobermoritic gels are yet the adecuates to difficult the ionic overset nessary to difficult the formation of that in each case until the age 21 days, and not when the pozzolana $D$ was only with $21,0 \% \mathrm{SO}_{3}$ how has happened in this work. So all that indicates the idea which as it seems, each total cuantity of ettringite to form in each case, needs a type gel tobermoritic determined in precise and adequated quality, $C / S$, and quantity g.Et./g.CSH gel, to difficult notably the formation of that.

On the other hand, the fact which in all cases is maintained and inclosed the small quantity of ettringite formed in origin in spite of the presence of pozzolana $D$ in them, point out yhe idea that the velocity of formation of tobermoritic gels of roign pozzolana $D$. must be apreciably less that the velocity formation of the ettringite of any origin at the initial ages of test, since in the contrary case this would must not appear since the origin.

Also and who will have it could be observed, before has been spoken of tobermoritic ge/s, (and has not been spoken of crystalline tobermoritic I or II Taylor, therefore the Graphic 2, do not confirms the presence of that) which have been in the medium in reason 

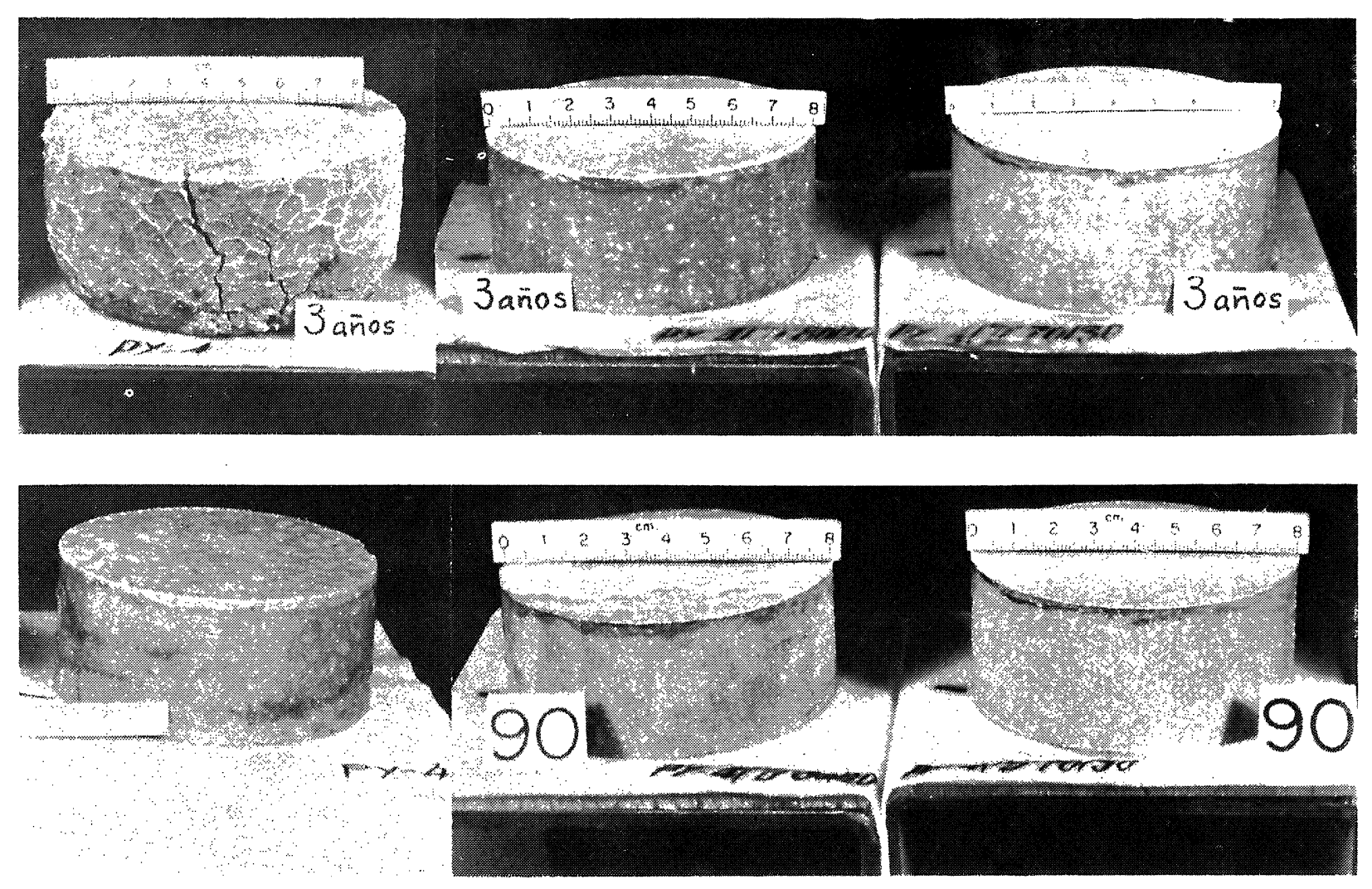

Foto 1
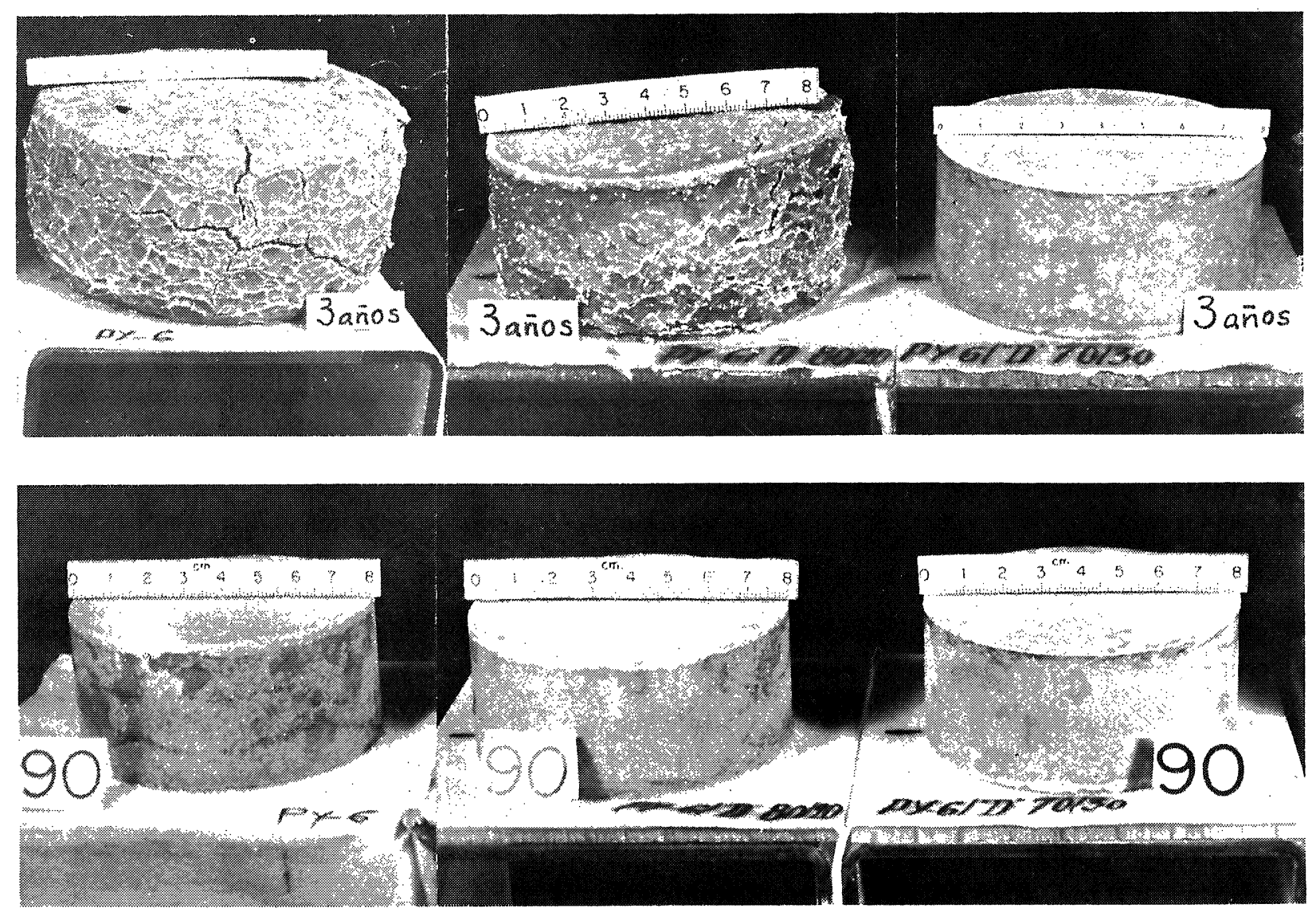

Foto 2 
los resultados obtenidos en el correspondiente ensayo de L-A, Fotos 1 y 2.

Del mismo modo tampoco se han detectado sulfato-silicatos de calcio hidratado similares a la ettringita o "Ettringita de $\mathrm{Si}^{4+}$ " en lugar de $\mathrm{Al}^{3+}$ ni SFCH, ni thaumasita, Gráfico 2).

\section{III.2. Ensayo de Le Chatelier-Anstett, L-A}

Entrando ahora en el análisis y estudio de los resultados obtenidos en el ensayo de L-A se observa como, según la especificación correspondiente, los seis cementos ensayados se pueden calificar de elevada resistencia sulfática, puesto que el valor del $\Delta \varnothing(\%)$ a laedad de 28 días no supera el 1,25\% propuesto por L. Blondiau. Pese a lo cual, llama poderosamente la atención que ello no se vea correspondido a la edad de 3 años nada más que por los cementos de mezcla PY-4/D 80/20 y 70/30 y PY-6/D 70/30, y no en cambio por los cementos PY-4, PY-6 y PY-6/D 80/20, Fotos 1 y 2, como también sería deseable. No obstante el hecho de que, Blondiau limitara hasta la edad de 90 dias de cada torta, el plazo de tiempo máximo permisible para la calificación del cemento que la constituye, venía a implicar que el citado autor admitía, con razón, que en tal plazo de tiempo se debía haber verificado casi la totalidad de las reacciones expansivas derivadas de la ettringita de origen $\mathrm{C}_{3} \mathrm{~A}$ del cemento constitutivo de la torta, y que ya lo que ocurra después de la edad de 90 días, no debería ser achacado a ettringita de tal origen. Por lo tanío, la autodestrucción selenitosa de tales tortas de los cementos PY-4, PY-6 y PY-6/D 80/20 a la edad de tres años (y no en cambio las de los cementos PY-4/D 80/20 y $70 / 30$ y PY-6D 70/30), ha de ser debido forzosamente a ettringita de otro origen, en este caso del $\mathrm{Al}^{3+}$ del $\mathrm{C}_{4} \mathrm{AF}$, que es la única fuente mayoritaria del mismo, la cual se podrá formar a edad tan posterior, siempre y cuando existan, para entonces, edad de 3 años, condiciones portlandíticas, de $\mathrm{pH}$ y selenitosas, necesarias y suficientes para ello, las cuales lógicamente se podrán alcanzar más y mejor con cementos $P Y$ que con $P$, y en los primeros si su contenido de $\mathrm{C}_{3} \mathrm{~S}$ es superior dei $56 \%$, según los resultados obtenidos de este trabajo. De aquí que ios cementos de mezcla de este trabajo, cuyas tortas no se han autoresquebrajado a la edad de 3 años, tengan que poseer un contenido inferior a dicho valor,

el PY-4/D 80/20, 46,55 \% C 3 S, $(58,19 \% \times 0,8)$

el PY-4/D 70/30, 40,74\% $C_{3} S,(58,19 \% \times 0,7)$ y

el PY-6/D 70/30, 40,73 \% C 3 S, $(79,43 \% \times 0,7)$. of the obtained results in the correspondent L-A test, Phots. 1 and 2. At same time, have been not detected SSCH similars at the ettringite, nor SFCH, Graphic 2.

\section{III.2. Le Chatelier-Anstett, L-A, Test}

Making now the anaiysis and study of the obtained results in the $L-A$ test, is observed how according to the correspondent specification the six cements tested are can calificated of high sulphatic resistance, since the value of the $\Delta \varnothing(\%)$ at the time of the 23 days is less that $1,25 \%$ of the initial diameter, $\varnothing_{0}$, proposed by Blondiau. In spite of that, it is eminent that it is not corresponded at the age 3 years only by the mixture cements $P Y-6 / D$ 70/30, PY-4/D 80/20 and PY-4/D 70/30, and no by the cements PY-4, PY- 6 and PY-6/D $80 / 20$, Phots. 1 and 2 , how it would be desidered. Nevertheless the fact of that Blondiau limited the space of time maximun permitted for the calification of the cement which forms until the age of 90 days of each tart, which implicated that cited author received reasonably that in this space of time it is must have verified almost the totality of the expansive reactions derivate of the ettringite of $\mathrm{C}_{3} \mathrm{~A}$ origin of cement constituient tart, and already that is occurred after the age of 90 days, would must not be accused at ettringite of such origin. Therefore the selenitic autodestruction of these tars of cements PY-4, PY-6 and PY-6/D 80/20 at the time of 3 years old (and notoin echange of the cements PY-6/D 80/20, PY-4/D 80/20 and PY-4/D 70/30) has be must necessarily at ettringite of other origin, in this case of $\mathrm{Al}^{3+}$ ion of $\mathrm{C}_{4} A F$, which it is the only originating cause of these, which would be couid forme at age oid aiways and when are at that time, age 3 years, necessarily and sufficient portlandiic, $\mathrm{pH}$ and selenitic conditions for these, that will be could follow better with cements type $V$ that with type I or II, and in the firsi if its content of $\mathrm{C}_{3} \mathrm{~S}$ is greater $56 \%$, according to resuits obtained of this work. From here that the mixture-cements of this work, which tarts have not been cracked by selenitic attack at the time 3 years, have to possess a content of $\mathrm{C}_{3} \mathrm{~S}$ smaller $56 \%$ the PY-4/D 80/20, 46,55\% $\mathrm{C}_{3} \mathrm{~S}(58,19 \% \times 0,8)$, the $P Y-4 / D 70 / 30,40,73 \% C_{3} S(58,19 \% \times 0,7)$ and the $P Y-6 / D 70 / 30,56,60 \%(79,43 \% \times 0,7)$. 

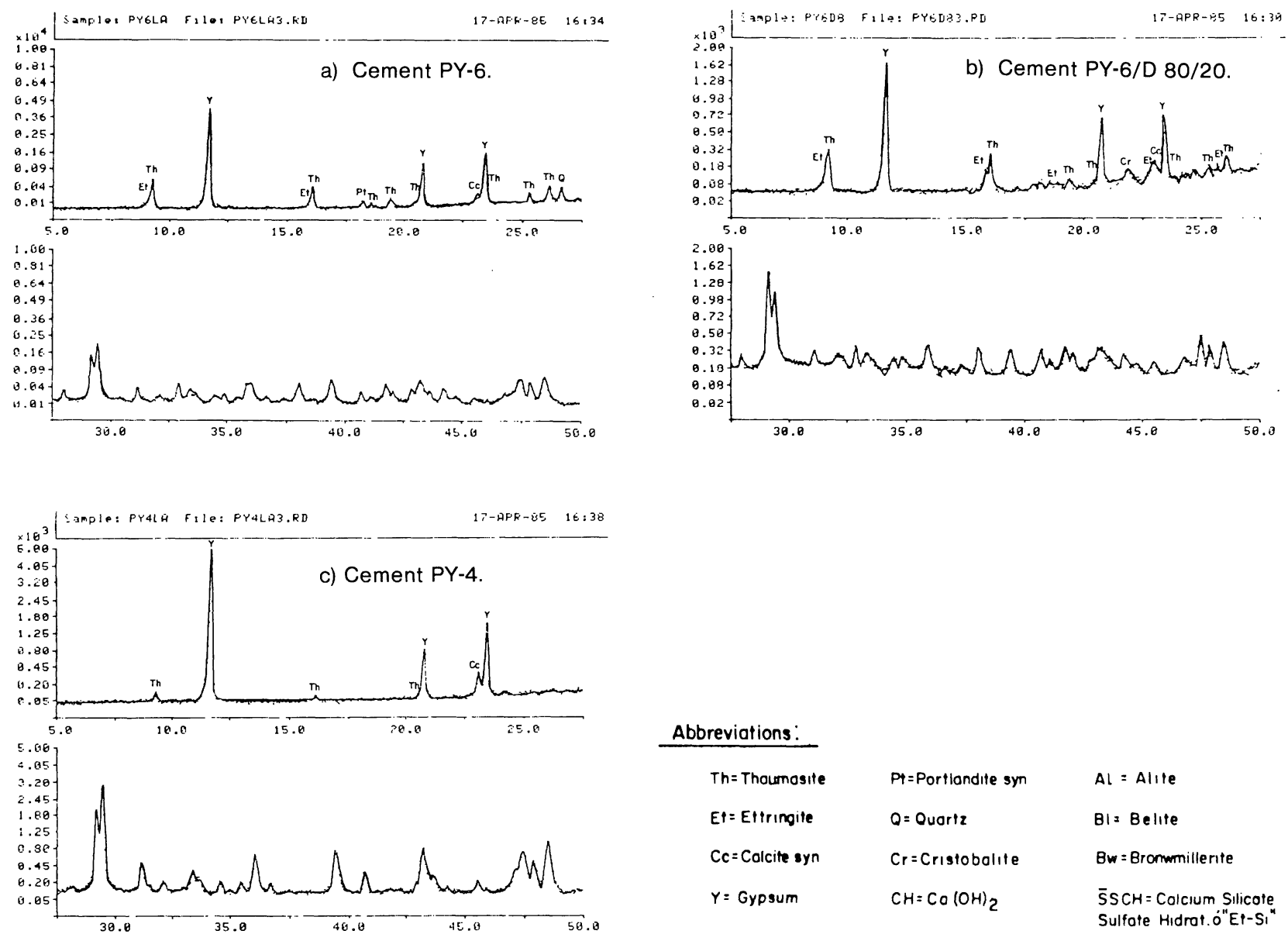

Graphic 3.-XRD tarts L-A of different cements; Age: 3 years.

Todo ello se ve además confirmado:

a) Por los correspondientes valores del ensayo de Fratini y en especial los de la [CaO] a 28 días de la fase líquida respectiva, los cuales a igualdad de todo lo demás han resultado ser siempre mayores, en el caso de que el cemento matriz constitutivo de tales cementos de mezcla ha sido el PY-6 y no el PY-4, por el mayor contenido de $\mathrm{C}_{3} \mathrm{~S}$ del primero sobre el segundo (véase Tabla 1) debiéndose mantener, lógicamente,a tales diferencias de [CaO], con mayor razón, conforme transcurre el ensayo.

b) Por el propio contenido de $\mathrm{C}_{4} \mathrm{AF}$ de ambos cementos PY-4 y PY-6.

- que al ser tan relativamente próximo, (véase Tabla 1) impide que las notables diferencias de $\Delta \varnothing$ mostradas por sus tortas respectivas a la edad de 3 años, $18,58 \%$, sean achacables a la diferencia de $\mathrm{C}_{4} \mathrm{AF}$ de signo contrario, $1,56 \%$, existente entre los mismos $y$, además,
All these is confirmed likewise:

a) By the correspondent values of Fratini test, Table 3, specially that fo ( $\mathrm{CaO})$ of respective liquid phase, that in equality of age and mixture cement always have been greatest, in the case of matrix portland cemet $P Y-6$ and not $P Y-4$, for the greatest content of $\mathrm{C}_{3} \mathrm{~S}$ of first on second, Table 1 , it must be logically to support these differences of $(\mathrm{CaO})$, with more reason, according to progress of the test,

b) By the proper content of $\mathrm{C}_{4} \mathrm{AF}$ of both cements PY-4 and PY-6, that

- which are so nearest, Table 1, invalid that the remarkable differences of $\triangle \varnothing(\%)$ showed by tarts respectiv at the time 3 years, $18,58 \%$, are imputed at the difference of $\mathrm{C}_{4} \mathrm{AF}$ of sign contrary, $1,56 \%$, that is in they, and forthermore, 
- si la causa principal fuera el mayor contenido de $C_{4} A F$, como ocurre comúnmente para el caso del $\mathrm{C}_{3} \mathrm{~A}$, debería haber sido la torta del cemento PY-4 la que más hubiese expandido a la edad de 3 años y más thaumasita hubiese formado (Gráfico 3 ) y no la del PY-6 como ha ocurrido en la realidad.

c) Por la detección por DRX de thaumasita en cada una de las tortas destruidas (Gráfico 3) y no en cambio de $\overline{S S C H}$, al igual que Lukas (8) (que la detectó en un túnel de hormigón dañado por sulfatos) y que como es sabido se forma de ettringita de origen $\mathrm{C}_{3} \mathrm{~A}$, con $\mathrm{SiO}_{2}$ y $\mathrm{CaO}$, la cual ha de provenir necesariamente en este caso de aquella cantidad de $\mathrm{C}_{4} \mathrm{AF}$ que posea mejores condicionantes del medio para originarla, los cuales han de ser obligatoriamente los del PY-6, como se confirma una vez más.

d) Por las cantidades de thaumasita originadas en las tres tortas resquebrajadas (Fotos 1 y 2 y Gráfico 3), las cuales han resultado proporcionales a los contenidos de $\mathrm{C}_{3} \mathrm{~S}$ de su f́racción portland respectiva PY-6, 79,43\%, PY-6/D $80 / 20,63,54 \%$ y PY-4, $58,19 \%$, y no en cambio, y como debiera, a los contenidos de $C_{4} A F$ de cada uno de ellos, según los cuales la del PY-6/D 80/20 debería haber sido la menor, superada por la del PY-6 y PY-4 por este orden, y no el contrario.

Por otra parte, de las últimas razones demostrativas, c) y d), se ha de deducir también que si la tahumasita se origina en un medio rico en $\mathrm{CaO}$ y $\mathrm{SiO}_{2}$, éste se deberá alcanzar mejor en el caso de la torta PY-6/D $80 / 20$ que en el caso de la torta PY-6, pues aquélla, al estar constituida por puzolana D (diatomita), de elevado contenido de sílice opalina, y por un contenido elevado de $\mathrm{C}_{3} \mathrm{~S}$ del $63,54 \%$, deberá reunir las mejores

condiciones para ello. Por lo que la cantidad de thaumasita originada en la misma debería haber sido en exclusiva, o al menos nétamente mayor que la del PY-6, y no al contrario como ha ocurrido en la realidad; ello unido a la razón d) anterior, confirma que dicha $\mathrm{SiO}_{2}$ opalina a edad de 3 años no debe encontrarse como tal, sino como CSH gel de distinta relación $\mathrm{C} / \mathrm{S}$ (inadecuada en este caso de la torta PY-6/D 80/20 y adecuada en el caso de las tortas restantes PY-6/D 70/30, PY-6/D $80 / 20$ y PY-4/D 70/30), por lo que la fuente aportadora del $\mathrm{CaO}$ y $\mathrm{SiO}_{2}$ necesarias para que se forme la thaumasita, ha de ser el $\mathrm{C}_{3} \mathrm{~S}$ en su proceso de hidratación, cuya primera fase deberá ser obligatoriamente la de la separación de los iones $\mathrm{Ca}^{2+}$ y $\mathrm{Si}^{4+}$ de su red cristalina correspondiente antes de constituir
- if the main cause were the great content of $C_{4} A F$, as occurs usually for the case of $C_{3} A$, would have be the tart of cement $P Y-4$ the greatest expansion at the time 3 years, and more thaumasite had be formed, and not tha tart of PY-6, as has occurred in the reality,

c) By the detection of tahumasite by means of $X R D$ in each tart cracked, Graphic 3, and not in change of SSCH, equal of Lukas (8) (that detected this in tunnel concrete damaged by suiphatic attack), and as it is knowed it is formed by ettringite of origin $\mathrm{C}_{3} \mathrm{~A}$ in a rich medium in $\mathrm{CaO}$ and $\mathrm{SiO}_{2}$, which must proceed necessarily of the taht quantity of $\mathrm{C}_{4} \mathrm{AF}$ which possess beter conditions of medium to origin it, in which have must be necessarily these of the PY-6 cement, as is confirmed again,

d) By means of the quantities of thaumasite origined in the tarts cracked, Phots, 1 and 2, and Graphic 3, which have resulted to be proportionals at the contents $C_{3} S$ of it fraction portland respective, $P Y-6,79,43 \%$ $C_{3} S, P Y-6 / D$ 80/20, 63,54\% $C_{3} S$ and PY-4 $58,19 \% C_{3} S$, and not for the contrary and as it sould be by calculations, at the contens of $C_{4} A F$ of each them, according to that, these quantity of thaumasite of $P Y-6 / D$ $80 / 20$, was must be the less exceed by of PY- 6 and PY-4, by this order, and not the contrary, as it has occurred in this work.

On the other hand of the last demosirative reasons $c$ ) and $d$ ), hs be deduced aiso that if the thaumasite is origined in a $\mathrm{CaO}$ and $\mathrm{SiO}_{2}$ rich medium, such medium would be obtained better in the case of the tart PY-6/D 80/20, that to be formed by diatomite pozzolana, $D$, with large content of opaline silica and by a large content of $\mathrm{C}_{3} S, 63,54 \%$, would be congregate the better conditions for that. In this reason the quantity of thaumasite origined in the tart PY-6/D 80/20 will ave been in exclusive, or at least more greater of PY-6, and not on the contrary, as has accounted in this work; that united at the last reason d), confirms that opaline silica at the time 3 years must not be as reactie silica if not as $\mathrm{CSH}$ gel of different $\mathrm{C} / \mathrm{S}$ relation (inadequate in this case of tart PY-6/D 80/20 and adequated in these case of tarts $P Y-6 / D$ 70/30, $P Y-4 / D$ 80/20 and $P Y-4 / D$ 70/30), for this cause the principal fountain arrived of the necessary quantities of $\mathrm{CaO}$ and $\mathrm{SiO}_{2}$ to be formed the thaumasite has to be the $\mathrm{C}_{3} S$ of portland cement fraction PY- 6 in it hydration process, which first phase will be neceserily the separation of the $\mathrm{Ca}^{2+}$ and $\mathrm{Si}^{4+}$ ions of the crystalline net of $C_{3} S$ before to forme portlandite syntetic and calcium silicates 
los $\mathrm{C}_{\mathrm{x}} \mathrm{S}_{\mathrm{y}} \mathrm{H}_{\mathrm{z}}$ finales respectivos, los cuales con su presencia constante en el tiempo deberán ser los que en definitiva actúen sobre la ettringita presente para que ésta pase a thaumasita. $Y$ prueba adicional de ello es que en la torta PY-4/D 80/20 aparece la thaumasita también, aunque lógicamente en menor medida por la razón anterior.

Por último, y como prueba adicional de que es el contenido de $\mathrm{C}_{3} \mathrm{~S}$ de cada cemento el que indirectamente está implicado tanto en un caso - torta rota - como en el otro - torta estable-, está el hecho ocurrido a las tortas PY-4/D 80/20 y PY-4/D 70/30, las cuales al tener su contenido de $\mathrm{C}_{3} \mathrm{~S}$ menor de $56 \%$ -y menor del 58,19\% del PY-4 sólo, $46,55 \%$ y $40,73 \%$, respectivamente-, con sus consecuencias pertinentes:

- C/S del CSH más adecuado,

- Ettringita total/CSH, más adecuado, y

- [CaO] de la fase líquida, menos adecuados que los de la torta del PY-4 sólo, deberán ya evitar la formación de ettringita o mejor thaumasita con sus consecuencias negativas pertinentes.

Y si el contenido de $\mathrm{C}_{3} \mathrm{~S}$ del cemento portland matriz constitutivo común del $80 / 20$ y $70 / 30$ tuviera mayor cantidad de $\mathrm{C}_{3} \mathrm{~S}$ que el PY-4, caso del PY-6, la torta estable se deberá conseguir con adiciones mayores del $20 \%$ de puzolana $D$, como así ha ocurrido con la PY-6/D 70/30 y no con la PY-6/D 80/20, y si fuera aún mayor tal contenido de $\mathrm{C}_{3} \mathrm{~S}$, con adiciones mayores del $30 \%$, y así sucesivamente.

\section{CONCLUSIONES}

1. No es imposible el ataque sulfático muy severo a los cernentos portland de elevada resistencia a dicho agresivo.

2. ${ }^{a}$ El empleo de puzolana tipo diatomita o similar con cementos portland de elevada resistencia al ataque de los iones sulfato puede evitar un ataque muy severo de aguas yesíferas.

3. La cantidad adicionada de puzolana tipo diatomita o similar, para eludir el ataque muy severo anterior, es función del contenido de $\mathrm{C}_{3} \mathrm{~S}(\%)$ de cemento portland de elevada resistencia sulfática con el que se va a mezclar y, asimismo, ha de ser función de la calidad C/S del gel y de la hydrated, which with constant presence although differents in the time will must be who will make that present ettringite pase at thaumasite, and as aditional proof of it is that the PY-4 have also thaumasite althugh logically in less quantity by lest reason at the time 3 years.

And at latest and as aditional proof of that is the quantity of $\mathrm{C}_{3} \mathrm{~S}$ of each cement who is implicating indirectly in a case - crack tartand the other - stable tart-is the fact happened at the -tarts $P Y-4 / D$ 80/20 and $P Y-4 / D$ 70/30 which have the content $C_{3} S$ less $56 \%$-and less $58,19 \%$ of the PY-4 alone, such contens are $46,55 \%$ and $40,73 \%$, respectivelly - with the correspondent consecuences,

- C/S of the CSH gel, more adequate,

- Ettringite total/CSH total, more adequate, and

- CaO liquid phase, less adequate,

which these of the tart PY-4, will must already elude the formation of ettringite or better thaumasite and this manner the cracking of the suitable tarts. And if content $\mathrm{C}_{3} \mathrm{~S}$ of the common constituye matrix portland cement of the mixture-cement $80 / 20$ and $70 / 30$ a quantity larger $58,19 \% C_{3} S$ (PY-4), case of $P Y-6$, will be must attain the stable tart with additions greater $20 \%$ of pozzolana $D$, as this maner has occurred with tart $P Y-6 / D 70 / 30$ and not with the tart PY-6/D 80/20.

\section{CONCLUSIONS}

1. It is not impossible the sulphate attack at the sulphate resistant portland cement.

2. The employment of a pozzolana type diatomite or similar with the sulphate resistant portland cement, can alude a rigorous sulphate attack.

3. The quantity additionated of pozzolana type diatomite or simila to elude it, is function of $\mathrm{C}_{3} \mathrm{~S}(\%)$ content of the sulphate resistant portland cement, at the same has must be function of the quality $(\mathrm{C} / \mathrm{S})$ and quantity (Ettringite total to form/Tobermoritic gels to form) of the 
cantidad (Ettringita total a formar/Geles tobermoríticos a formar) de los geles tobermoríticos, en cada caso.

4. ${ }^{a}$ La velocidad de formación de la ettringita de cualquier origen deber ser mayor que la velocidad de los geles tobermoríticos de la puzolana $\mathrm{D}$ a las edades iniciales del ensayo.

5. ${ }^{\text {a }}$ El buen comportamiento de los cementos puzolánicos de este trabajo, ante el ataque del yeso, no es generalizable a TODOS los cementos puzolánicos, ocurriendo otro tanto con aquellos otros que han mostrado un mal compotamiento [Véase al efecto la Tesis Doctoral de R. Talero (9)].

6. ${ }^{a}$ El método del ensayo L-A juzga fundamentalmente a la edad de 28 días (inclusive la de 90 días), la nocividad mayor o menor derivada,

- del $\mathrm{C}_{3} \mathrm{~A}$ de un cemento portland P ó PY al ser atacado por iones sulfato ( $y$ no tanto la derivada, en su caso, de su $\mathrm{C}_{4} \mathrm{AF}$ acompañante, pues ésta se habría de juzgar con bastante posterioridad), $\mathrm{y} / \mathrm{o}$

- de la(s) puzolana(s), en su caso, que acompañe(n) al $\mathrm{P}$ y/o al PY anterior(es). [véase al efecto la Tesis Doctoral de R. Talero (9)]. tobermoritic gels, in each case.

4. The velocity formation of the ettringite of any origin must be greater than the velocity of formation of the tobermoritic gels of pozzolana $D$ at the initial ages of the test.

5. The good behaviour from the pozzolanic cements of this work before the gypsum attack is can not be generalized at $A L L$ the pozzolanic cements, accounting equally with those others which have showed a bad behaviour [See the Doctoral Thesis of R. Talero (9) beside].

6. ${ }^{a} \quad$ L-A test method records specially for age 28 days (and 90 days too), the more or less noxiousness derived from,

- the $C_{3} A$ content in a $P$ or PY portland cement, when it is attacked by sulphate ions (not exactly from it, as from the $C_{4} A F$ which accompaies it, for this should be estimated lately), and/or,

- the pozzolane(s) which in its respective case, accompanies former $P$ or PY portland cements [see the Doctoral Thesis of R. Talero (9) beside].

\section{REFERENCES}

(1) P. K. MEHTA: "Effect of the Lima on Hydration of Pastes Containing Gypsum and Calcium Aluminates or Calcium Sulfoaluminates. J. Am. Cer. S, 56, (6) 198.

(2) M. COLLEPARDI, S. MOROSI, G. MORICONI and M. CORRADI: "Tetracalcuim Aluminoferrite Hydration in the Presence of Lime and Gypsum". Cement and Concrete Research, 9, 431-37, 1979.

(3) H. KÜHL: Zement Chemie, T. III, 118-130, 3. ${ }^{a}$ ed., 1961.

(4) G. L. KALOUSED, L. C. PORTER and E. J. BENTON: "Concrete for Long-Time Service in Sulphate Environment". Cement and concrete Research, Vol. 2, No. 1, 79-89, 1972.

(5) L. BLONDIAU: "Considerations diverses relatives a l'essai de resistenza chimique au sulfate de calcium suivant le processus Le Chatelier-Ansttet. Rev. Mat. Constr. Trav. Pub., III, No. 524, 1961

(6) Pliego de Prescripciones Técnicas Generales para la Recepción de Cementos, RC-75.

(7) P. LAPOUJADE and P. VOGEIN: Bull. Soc. Franc. Ceram. (28), 3-12, 1955.

(8) W. LUKAS: "Betonzerstörung durch $\mathrm{SO}_{3}$-Angriff unter Bildung von Thaumasit und Woofordit". Cement and Concrete Research, Vol. 5, No. 5, 503-18, 1975.

(9) R. TALERO: "Contribution at the Analytical and Physic-Chemistry Study of the System: Pozzolanic Cement-GypsumWater at 22 + 3 C". Doctoral Thesis, Ftad. de Ciencias Químicas, Universidad Complutense de Madrid e Instituto "Eduarto Torroja" de la Construcción y del Cemento, nov. 1986, Madrid, Spain. 